\title{
Comprehensive Evaluation on Status and Changes in Fishing Practices of Migratory Fishermen in Cochin Back Waters
}

\author{
P. Srikanth ${ }^{1 *}$, A. Balasubramanian ${ }^{2}$, K. Jyotsna Rajeswari ${ }^{3}$, \\ G. Suresh ${ }^{4}$ and B. Manoj Kumar ${ }^{5}$ \\ ${ }^{1}$ Krishi Vigyan Kendra, Undi, ANGRU, Andhra Pradesh, India \\ ${ }^{2}$ Department of Fisheries Resource Management, College of Fishery science, Muthukur, \\ Nellore, Andhra Pradesh, India \\ ${ }^{3}$ Sri MVKR Fishery Polytechnic College, Bavadevarapalli, SVVU, Andhra Pradesh, India \\ ${ }^{4}$ Department of Aquaculture, College of Fishery science, Muthukur, Nellore, \\ Andhra Pradesh, India \\ ${ }^{5}$ Department of Fisheries Engineering \& Technology, KUFOS Panangad, Kochi, Kerala, India \\ *Corresponding author
}

\section{A B S T R A C T}

Comprehensive investigation on status and changes in fishing practices of migratory

\section{Keywords}

Migratory fishermen, Coracle, Set gillnet, fishing

Article Info

Accepted:

10 October 2018

Available Online:

10 November 2018

fishermen in Cochin backwaters, Kerala was conducted for a period of one year from June 2016 to May 2017. Identified predominant habitats of migratory fishermen viz., Nettor, Vypin and Mulavukadu were identified. Data on type of crafts, gears, and fish catch composition obtained from these gears were collected fortnightly from these study areas. The coracle and bottom set gillnet were the predominant raft and fishing gear used by the migratory fishermen of the study areas. Technical details of both raft and gears were recorded. Different type of bottom set gillnets used by the fishermen were locally known as 'Njanduvala' with mesh size of 90 to $150 \mathrm{~mm}$, 'Karimeenvala' with $50 \mathrm{~mm}$ and $70 \mathrm{~mm}$ and for 'Koori vala' having mesh size of 40 to $60 \mathrm{~mm}$. The twine thickness for all these nets was 0.1 to $0.2 \mathrm{~mm}$. The Hanging co-efficient was $0.4-0.6$ for both 'Njanduvala', and 'Karimeenvala while it was 0.5 to 0.6 for 'Koori vala'. Main catch from the former two gears were crabs and targeting pearl spot (Etroplus suratensis) and catfishes from the later one.

\section{Introduction}

Globally fisheries sector is gaining momentum due to its significant contributions to the humankind by providing financial security to over 14 million people by providing employment. It is estimated that 56.6 million people were engaged in the primary sector of capture fisheries and aquaculture in 2014 as full and part time). Judicious tapping of fisheries resources is imperative to bridge protein requirement with rapidly multiplying human population. This can be possible by elevating the fish production through fishing and aquaculture means. Fishing which is considered as one of the ancient occupation of 
the humankind originated along with hunting. The fishing can be classified as subsistence, small scale and large scale based on the inputs involved. Marine fishing in India can be grouped under small scale or large scale fishing. Even though Kerala is immensely gifted with inland water resources, the fishing activity in the inland sector is mainly in small scale and for the majority of the fishermen, it is only subsistence fishing. The inland resources of the state include both freshwater and brackish water. The total area of all these resources together is about 2,26,274 ha. The brackish water bodies of the state include 49 inter-connected backwaters which form more than 46,000 ha in area. Cochin back waters which form a part of the Vembanad Lake and Ashtamudi Lake are two important brackish water areas of the state, both of which have been declared as Ramsarsite.

According to the statistics of the Kerala state fisheries department, the total inland fishermen population of the state is 10.24 lakh. The main gears used in the brackish water sector of the state are stake nets, dip nets and gill nets. The present inland fish production of the state was 2.1 Lakh tonnes during the year 2014-2015. Poor production from these inland water bodies are mainly due to general trend in the country siltation, profuse weed infestation, pollution, construction of barricades and fishing with small mesh nets (Sugunan and Sinha, 2001). VembanadLake is the largest and the most important water body which fetches the livelihood for inland fishermen especially for the migratory fishermen who migrated from Karnataka. Presence of these fishermen in these regions has led to conflicts with the local fishermen (Hornell, 1925; Gopinath, 1953; Shetty, 1965; and Kurup, 1982). There is no study yet conducted on fishing activities of migratory fishermen in the Cochin back waters. Owing to these, the present study was undertaken to evaluate the status and fishing practices being carried out by the migratory fishermen

\section{Materials and Methods}

Study was carried out for a period of one year from June 2016 to May 2017 in the Cochin backwaters, Kerala. During the study important settlements of migratory fishermen viz., Nettor, Vypin and Mulavukadu were identified for fortnight collection of data on gears, crafts and fishing methods employed by migratory fishermen of these regions. In addition to that species wise catch and total catch were also recorded. All these data were collected through visual observation and personal interview with randomly chosen fishermen from the study areas. The socio economic and techno economic details of the fishermen were also collected based on two pre-tested interview schedules.

\section{Design and technical details of crafts}

Various technical details about the crafts such as type of material, length overall (LOA), beam, draft, depth, diameter, weight, type of construction life span of the craft, and preservatives used were collected. Perspective drawings of craft and gears were made.

\section{Design and technical details of fishing gears}

The design features of nets were collected and documented according to FAO catalogue on fishing gear design (Nedelec, 1975 and Kazi et al., 2011). The design drawings of the nets were drawn to scale by using coral draw software. The units were indicated in metric equivalents viz., metre (m) for longer dimension such as lengths of head rope, foot rope and float line with two decimals and millimetre $(\mathrm{mm})$ for shorter dimensions such as stretched mesh size, diameter of rope and floats \& sinkers. The unit of weight was given in kilogram $(\mathrm{g})$. The size of netting yarn was 
designated according to the Tex system for multifilament. The hanging ratio (E), i.e., the length relation between the head rope and the netting to be attached to it, was estimated (Parsa et al., 2014). The symbols in the fishing gear drawing were used as per Nedelec (1975), The operational aspects of gillnet such as fishing ground, duration of the trip, depth of operation, mode of operation, etc. were collected using structured schedule

\section{Results and Discussion}

The migratory fishermen are mainly concentrated at Nettoor, Vypin, Mulavukadu region in the Cochin backwaters. They are mainly from Unsoor (near Mysore), Karnataka. Nettor has two families while Mulavukad and Vypin have 3 each. In a family about 4-5 members are involved in fishing.

\section{Details of the fishing raft employed by Migratory fisherman}

The raft used by migratory fishermen is coracle which is a saucer in shape. The dimension of the coracle is $15-25 \mathrm{~cm}$ in depth and $2.0-2.4 \mathrm{~m}$ dia. and is made with bamboo strips. This skeleton is covered with Palmyra leaves or HDPE sheets. Outer edge of the craft is strengthened using several layers of bamboo strips and cloths or plastic sheet (Fig. 1). One or two coats of coal tar is given to the outer surface to make the craft waterproof. Weight of a coracle ranges from $10-20 \mathrm{~kg}$ and cost ranges from Rs. 5000 - 6000/-.

Details regarding the craft and other operational details are given in the Table 1. Usually two fishermen carry out fishing from a coracle. One person will be engaged in controlling the coracle while other in operating the fishing gear. Sometimes women are also engaged in fishing. Oars are used for propulsion. Oars are having length of $1.3 \mathrm{~m}$ out of that $1 \mathrm{~m}$ is the stick length and $30 \mathrm{~cm}$ is the wooden plane. The average life span of a coracle is 7 months. The coracle is the only craft used by the migratory fishermen of Cochin back waters which is locally known as "Kottavanchi" or "Vattavanchi". The coracles are exclusively used in all backwater areas and rivers in Kerala by the migratory fishermen from Karnataka (Remesan and Ramachandran, 2005). It was observed in the present study that every family of the migratory fishermen had 3-4 coracles of different sizes and the life span of a coracle was about 1 year. These coracles were brought from Karnataka. Various type of gillnets are operated from the coracle by the migratory fishermen. All members of the migrant fishermen family including women and children are experts in the operation of coracles.

\section{Details of the fishing gear employed by Migratory fisherman}

Gill nets are the only gear used by the migratory fishermen in the landing centres studied. The type of operation of the gear is bottom set in nature. The design details of the gears used are given in Table 2. Based on the design of the net and species caught the gears are named as 'Karimeenvala' (Etroplus net), 'Koori vala' (cat fish net) and 'Njanduvala' (Crab net).

All these nets are operated throughout the year. Based on the tides and water depth, the depth and length of the net is changed by the fishermen. The fishermen operate the nets during morning (6am - 9 am) and evening (4.30 - $7 \mathrm{pm}$ ). The duration of fishing hours is 2 to $3 \mathrm{~h}$. In every trip 7 to 10 nets of different types are operated. The type of net to be operated is decided with reference to the catch obtained in the previous haul. These gillnets operated with the aim to target a particular group of fish (Remesan and Ramachandran, 2005). 
Table.1 Details of the raft operated by Migratory fishermen

\begin{tabular}{|c|c|c|c|}
\hline SI. No & Nettor & Vypin & Mulavukad \\
\hline Category of vessel & $\begin{array}{l}\text { Non-Motorized } \\
\text { (coracle) }\end{array}$ & $\begin{array}{l}\text { Non-Motorized } \\
\quad \text { (coracle) }\end{array}$ & $\begin{array}{l}\text { Non-Motorized } \\
\text { (coracle) }\end{array}$ \\
\hline LOA of fishing craft(m) & $2-2.5$ & $2-2.5$ & $2-2.5$ \\
\hline Life span of craft & 7months & 7months & 7months \\
\hline No.of crafts & 5 & 6 & 8 \\
\hline No.of members operated & 4 & 6 & 6 \\
\hline Cost of craft & 7000 & 7000 & 7000 \\
\hline Make of craft & $\begin{array}{l}\text { Tar, bamboo sticks } \\
\text { plasticjack, saree } \\
\text { cloths }\end{array}$ & $\begin{array}{c}\text { Tar, bamboo } \\
\text { sticks plasticjack, } \\
\text { saree cloths }\end{array}$ & $\begin{array}{c}\text { Tar, bamboo sticks } \\
\text { plasticjack, saree } \\
\text { cloths }\end{array}$ \\
\hline No. of crafts operated & 2 & 2 & 2 \\
\hline No. of crew & 2 & 2 & 2 \\
\hline No. Fishing days in month & $25-26$ & $25-26$ & $25-26$ \\
\hline Fishing season & Throughout the year & $\begin{array}{l}\text { Throughout the } \\
\text { year }\end{array}$ & $\begin{array}{c}\text { Throughout the } \\
\text { year }\end{array}$ \\
\hline $\begin{array}{l}\text { Distance of the fishing } \\
\text { ground }(\mathrm{km})\end{array}$ & 1 to 2 & 1 to 2 & 1 to 2 \\
\hline No. of operations per day & 1 to 2 & 1 to 2 & 1 to 2 \\
\hline Fishing time & $\begin{array}{l}6 \mathrm{am}-10 \mathrm{am} \\
5 \mathrm{pm}-7 \mathrm{pm}\end{array}$ & $\begin{array}{l}\text { 6am-10am } \\
4 \mathrm{pm}-6 \mathrm{pm}\end{array}$ & $\begin{array}{l}\text { 6am-10am } \\
4 \mathrm{pm}-6 \mathrm{pm}\end{array}$ \\
\hline $\begin{array}{l}\text { Quantity of ice used per } \\
\text { month(kg) }\end{array}$ & $10-12$ & $10-12$ & $10-12$ \\
\hline $\begin{array}{l}\text { ACESSORIES used for } \\
\text { fishing }\end{array}$ & $\begin{array}{c}\text { Oars \& thermocole } \\
\text { (for sitting inside the } \\
\text { coracle) }\end{array}$ & $\begin{array}{c}\text { Oars \& } \\
\text { thermocole (for } \\
\text { sitting inside the } \\
\text { coracle) }\end{array}$ & $\begin{array}{l}\text { Oars \& thermocole } \\
\text { (for sitting inside } \\
\text { the coracle) }\end{array}$ \\
\hline $\begin{array}{l}\text { Operational cost per } \\
\text { trip(Rs) }\end{array}$ & 100 & 100 & 100 \\
\hline
\end{tabular}


Table.2 Design features of gillnets operated by migratory fisherman

\begin{tabular}{|c|c|c|c|}
\hline Characteristics of the Net & \multicolumn{3}{|c|}{ Bottom set gillnet } \\
\hline Local name of the net & 'Njanduvala' & 'Karimeenvala' & 'koori vala' \\
\hline Main webbing mesh size(mm) & $150 \mathrm{~mm}$ & $40-60$ & $50-70 \mathrm{~mm}$ \\
\hline Type of twine & PA mono & Pa mono & Pa mono \\
\hline $\begin{array}{l}\text { Twine specification } \\
\text { diameter }(\mathrm{mm})\end{array}$ & 0.2 & $0.10-0.2$ & $0.10-0.2$ \\
\hline No of meshes in depth & 100 & 50 & 33 \\
\hline $\begin{array}{l}\text { Horizontal hanging coefficient } \\
\left(\mathrm{E}_{1}\right)\end{array}$ & 0.6 & $0.4-0.6$ & $0.5-0.6$ \\
\hline $\begin{array}{l}\text { Vertical hanging coefficient } \sqrt{ } 1- \\
\left(E^{2}\right)\end{array}$ & 0.64 & $0.5-0.7$ & $0.5-0.7$ \\
\hline $\begin{array}{l}\text { No.of meshes along head rope } \\
\text { per unit }\end{array}$ & 363 & 2800 & 1650 \\
\hline Hung length (m) & 32.67 & 77 & 57.75 \\
\hline Hung depth & 9 & 1.76 & 1.67 \\
\hline Colour of webbing & green & white & green \\
\hline Selvedge twine type & multifilament & multifilament & multifilament \\
\hline Selvedge diameter(mm) & $210 \times 2 \times 3$ & $210 \times 1 \times 2$ & $210 \times 1 \times 2$ \\
\hline Selvedge mesh size(mm) & 155 & $55 \mathrm{~mm}$ & 70 \\
\hline No. of selvedge meshes in depth & 1 & 1 & 1 \\
\hline Head rope material & PP & PP & PP \\
\hline Head rope diameter & $4 \mathrm{~mm}$ & $4 \mathrm{~mm}$ & $4 \mathrm{~mm}$ \\
\hline float material & thermocol & thermocol & thermocol \\
\hline Float dimension(mm) & $70 \times 60$ & $40 \times 36$ & $40 \times 36$ \\
\hline No of floats per unit & 15 & 50 & 70 \\
\hline Foot rope material & PP & PP & PP \\
\hline Foot rope diameter(mm) & 2.5 & 2.5 & 2.5 \\
\hline Sinker material & lead & Lead & lead \\
\hline Sinker weight (g) & 8 & 5 & 5 \\
\hline No. of sinkers per unit & 33 & 77 & 57 \\
\hline Total fleet length(m) & $33 \times 3=99$ & $77 \times 2=140$ & $57 \times 2=114$ \\
\hline
\end{tabular}


Details of the fishing raft employed by migratory fisherman

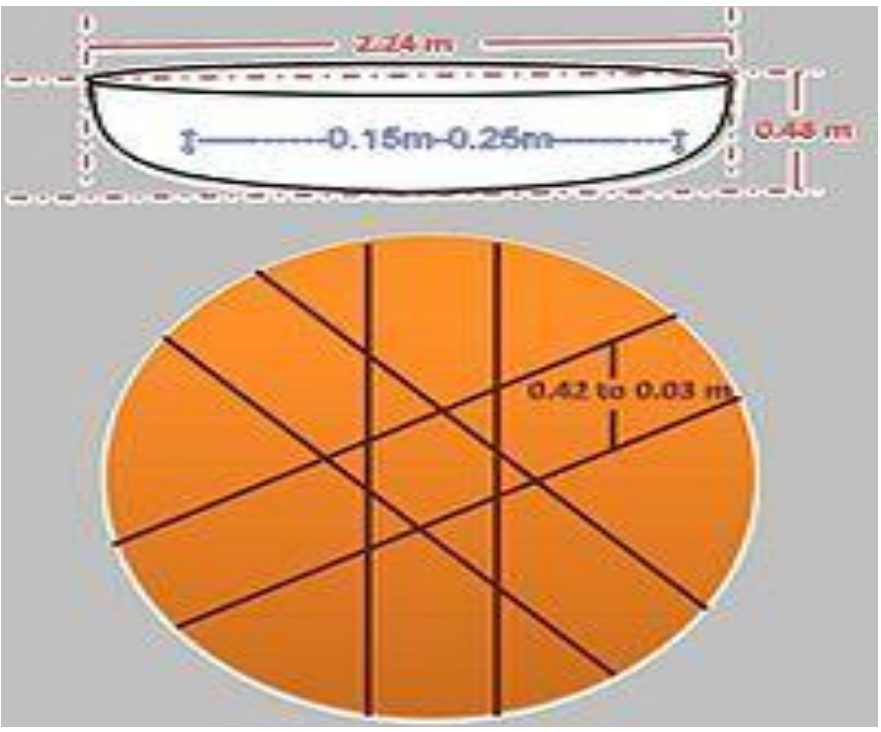

Fig.2 Njandu vala

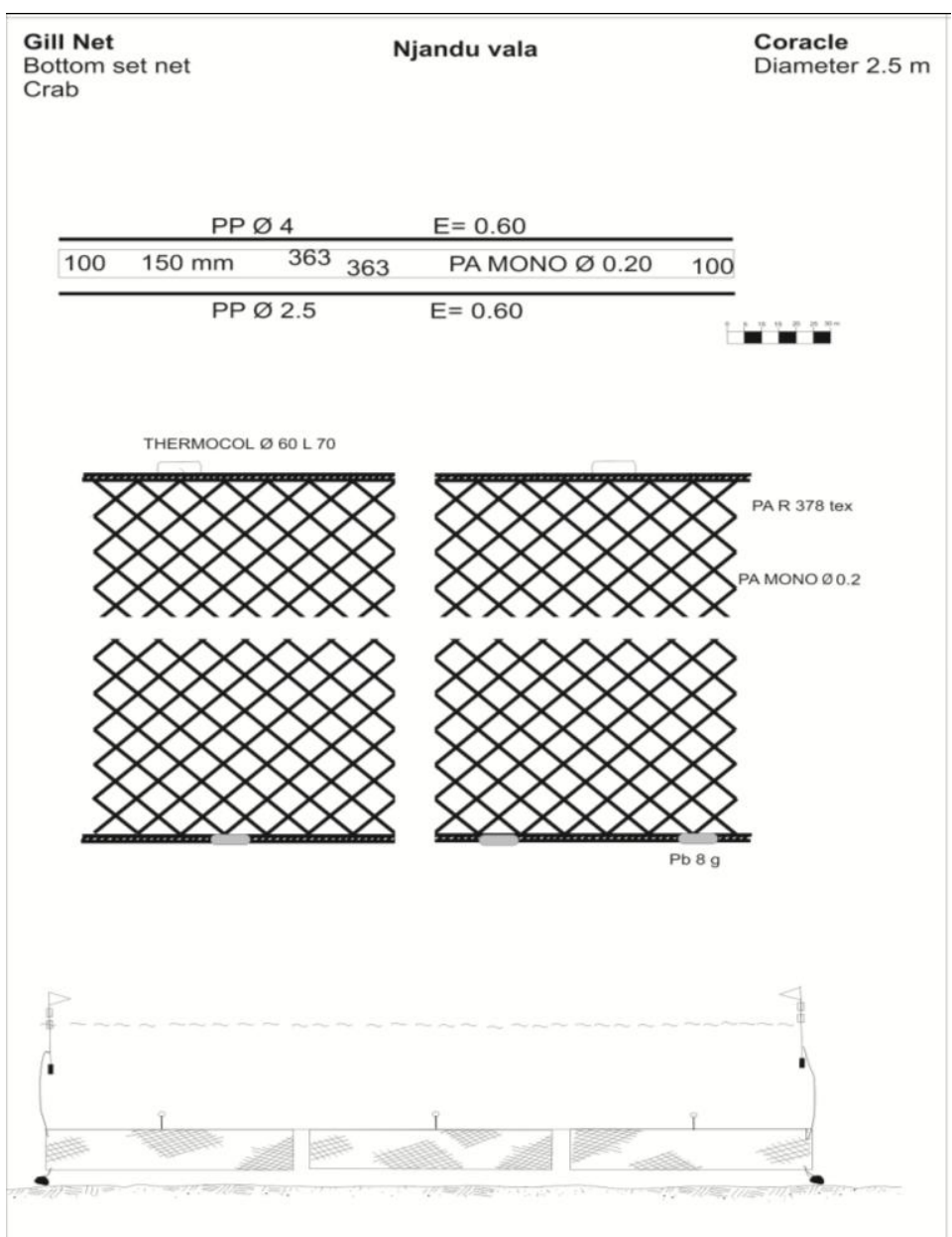


Fig.3 Karimeen Vala

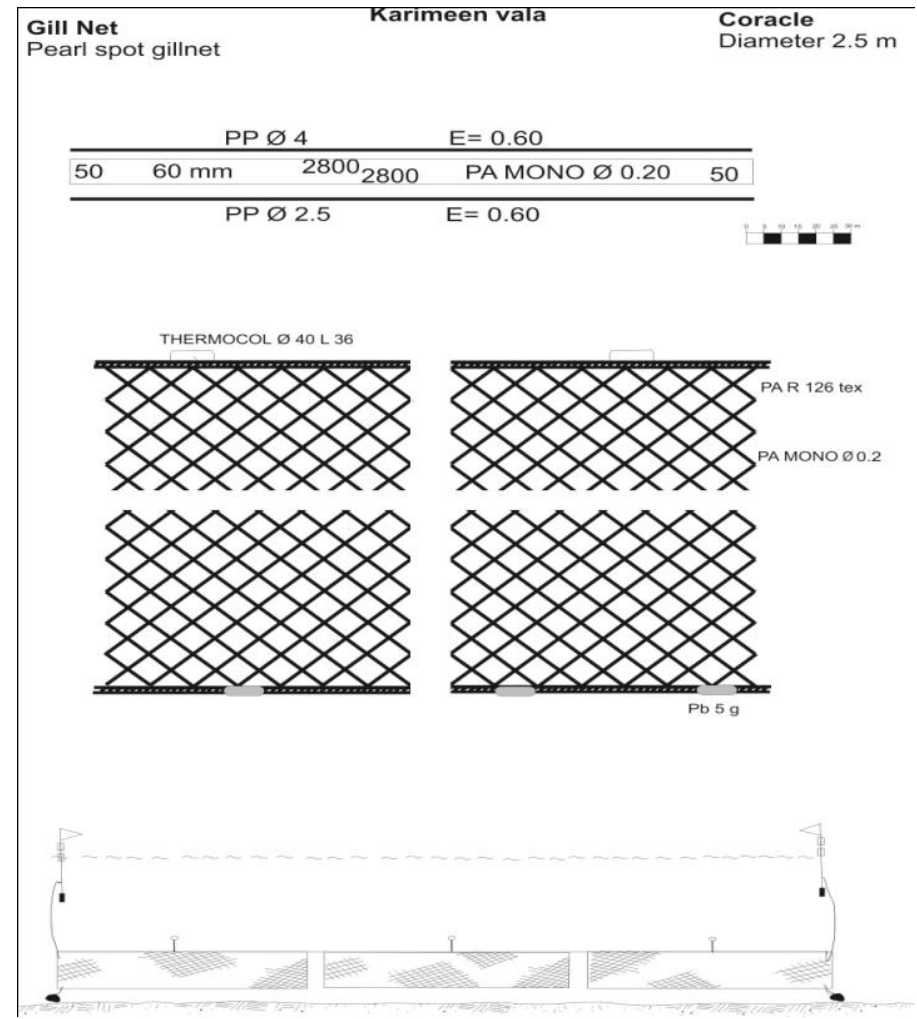

Fig.4 Koori Vala

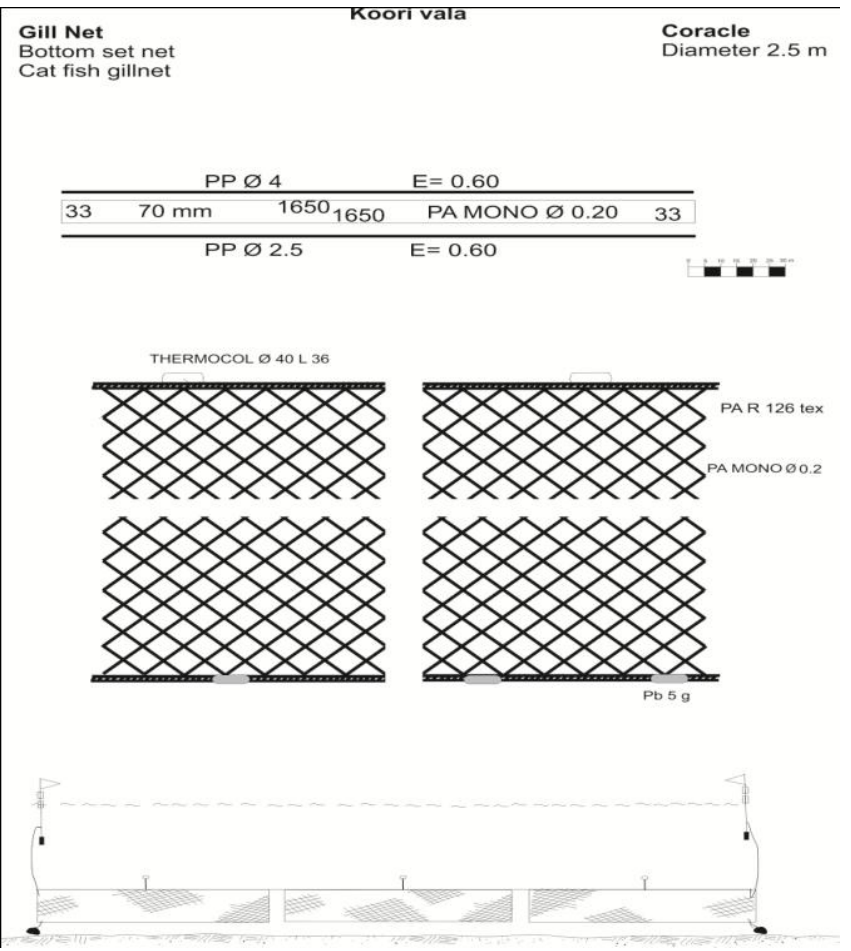


It was observed that the migratory fishermen are using different bottom set gillnets with different mesh sizes to exploit the both column and bottom dwelling fishery resources. The technical details of the fishing gears used by the migratory fishermen are given in Table 2. The major fishing gears used by these fishermen are Njanduvala which is an entangling net (Fig. 2) and species capture is mud crab Scylla serrata. The other gear is Karimeenvala which is a bottom set gillnet (Fig. 3) operated by the migratory fishermen in the Cochin backwaters as the name indicates the gear is used for capturing Karimeen (Etroplus sp.). The third gear used by the fishermen is Bottom drift gillnet which is locally called as 'koori vala' (Fig. 4) and made up of monofilament. This gear mainly target catfishes such as Horabagrus brachysoma, Arius subrostartus and flat fish Cynoglossus semifasciatus.

Though Migratory fishermen operate all these three gears with various ranges of mesh sizes, they generally restrict these nets only to two category of small and large mesh size. In the case of Njanduvala, the small and larger mesh sizes are $70 \mathrm{~mm}$ and $150 \mathrm{~mm}$ respectively. Similarly in the 'koori vala', the small and larger mesh size frequently used are $50 \mathrm{~mm}$ and $110 \mathrm{~mm}$ respectively while in 'karimeenvala' respective two mesh sizes are $36 \mathrm{~mm}$ and $120 \mathrm{~mm}$. These observations are lined with the observation of Remesan (2006), who studied the inland fishing craft and gears of north Kerala.

Ramachandran (2005) reported that the fabrication materials used for these gillnets used by the migratory fishermen is PA monofilament webbings. The twine used in 'Njanduvala' is thicker than the twine used in other gear since it is an entangling net thicker twine is used. Remesan and Ramachandran (2005) also found that the PA twine is used to fabricate gillnets of migratory fisherman with the specification of $210 \mathrm{D} \times 1 \times 2$ and $210 \mathrm{D}$ $\mathrm{x} 1 \mathrm{x} 3$. From this it is evident that the same practice is followed with the little modifications by the migratory fishermen of Cochin back waters also. It was further observed the thickness of the material used by the migratory fishermen for making gill nets is $0.16-0.23$ for 'koori vala' and karimeenvala and $0.20-0.23$ for Njanduvala irrespective of the mesh size. The reason for

Using thinner monofilament for making the webbing may be for making the netting material less visible during operation. The hanging coefficient of different gillnets of migratory fishermen was observed to be between 0.4 and0.7 for the purpose of keeping the meshes intact while operation. Remesan and Ramachandran (2005) has recorded the range of hanging coefficient of bottom set gillnets of the migratory fishermen as 0.3 to 0.6. Ideal hanging coefficient for driftnet would be 0.5-0.6(Parsa et al., 2014) since it increases the fishing efficiency. Hanging coefficient is $0.4-0.6$ for the bottom set gillnet (Remesan, 2006) It is opined that the hanging coefficient has less impact on catching efficiency in bottom set gillnets since it catches the fishes mainly through entangling than gilling. Migratory fishermen from Karnataka uses reeds collected from nearby areas as floats (Remesan and Ramachandran 2005).

In the present study, it was observed that thermocol pieces of the dimension of $70 \mathrm{~mm} \times 60 \mathrm{~mm}$ was used as floats for the large mesh size njanduvala. The float used in karimeenvala and koorivalais $40 \mathrm{~mm} \times 36 \mathrm{~mm}$. Distribution of floats in the head rope depends on the size of the float as well as the mode of operation. Lead sinker is commonly used in gill nets, the size, shape and weight varies according to the type of net and mode of operation. Some fishermen use burnt clay and concrete disc. Stones and pieces of earthen 
tiles are also in use. The quantity of lead used is high in bottom set nets. For making njanduvala $100 \mathrm{~m}$ length the lead required is $4 \mathrm{~kg}$ and for one $\mathrm{kg}$ of net $3 \mathrm{~kg}$ of the lead is used for sinkers. The maximum life span of a net is one month and later the nets are bunt to recover the lead attached to the nets. Molten lead is again made into plate and reused for making sinkers.

Migratory fishermen operates wide range of gillnets with different mesh sizes utilizing all strata of ecosystem of back water of Cochin waters to capture various variety of species to meet their livelihood. The fishing practices followed by the migratory fishermen may deplete the inland fishery resources of Cochin back waters since they capture all kind of fishes irrespective of sizes throughout the year and not letting the fishes to spawn once. It may be endanger to the aquatic ecosystem of the study area in the Cochin back waters. Regulation on fishing practices followed by the migratory fishermen is highly essential to manage and conserve the depleting inland fishery resources of the region.

\section{References}

Gopinath K. Some interesting methods of fishing in the backwaters of Travancore. J. Bombay Nat. Rist. Soc., 1953; 51: 466-71.

Hornell J. The fishing methods of Madras Presidency, Part I. The Coromandel Coast. Madras. Fish Bull. 1925, 18 (2); 59-110.
Kazi, TG. Mohite, A. S., Jadhav, R. Design and general characteristics of sole fish gill nets of Ratnagiri, Maharashtra. Indian J. mar. Sci. 2011; 40, 722-724.

Kurup BM. Studies on the systematic and biology of fishes of the Vembanadlake. Ph.D. Thesis, University of Cochin.1982, 683.

Nedlec C. FAO Catalogue of Small Scale Fishing Gear, Fishing News. (Books) Ltd., Farham, Surrey, England. I975, 191.

Parsa, M., Paighambari, S. Y., Ghorbani, R., \& Shabani, M. J. Effects of Hanging Ratio on the Catch Rate and Catch per Unit Effort (CPUE) of Tuna Drifting Gillnets in Bushehr Coastal Waters, Persian Gulf (Iran). World Journal of Fish and Marine Sciences, 2014; 6(3); 214-218.

Remesan MP. Studies on Inland Fishing Gears of North Kerala. (Doctoral dissertation, Cochin University of Science and Technology). 2006, 25113.

Remesan, M.P. and Ramachandran, Gill nets for inland fishing in North Kerala. Fishery Technology, 2005; 42(2); 125134.

Shetty, HPC. Observation on the fish and fisheries of Vembanad backwaters, Kerala. Proc. Natn. Acad. Sci. India., 1965; 35 (1); 115-130.

Sugunan VV. and Sinha M. Sustainable capture and culture based fisheries in fresh waters of India. ln: Pandian, T. J. (eds.) Sustainable Indian Fisheries, 2001.

\section{How to cite this article:}

Srikanth, P., A. Balasubramanian, K. Jyotsna Rajeswari, G. Suresh and Manoj Kumar, B. 2018. Comprehensive Evaluation on Status and Changes in Fishing Practices of Migratory Fishermen in Cochin Back Waters. Int.J.Curr.Microbiol.App.Sci. 7(11): 1279-1287.

doi: https://doi.org/10.20546/ijcmas.2018.711.149 